\title{
Talabostat Mesylate
}

National Cancer Institute

\section{Source}

National Cancer Institute. Talabostat Mesylate. NCI Thesaurus. Code C80682.

The mesylate salt of an orally active small molecule with antineoplastic and hematopoiesis- stimulating activities. By cleaving N-terminal Xaa-Pro or Xaa-Ala residues, talabostat inhibits dipeptidyl peptidases, such as fibroblast activation protein (FAP), resulting in the stimulation of cytokine and chemokine production and specific T-cell immunity and T-cell dependent activity. This agent may also stimulate the production of colony stimulating factors, such as granulocyte colony stimulating factor (G-CSF), resulting in the stimulation of hematopoiesis. Dipeptidyl peptidases are involved in the activation of polypeptide hormones and chemokines. 